\title{
Wheat yellow mosaic virus Widely Occurring in Wheat (Triticum aestivum) in China
}

Chenggui Han, Dawei Li, Yiming Xing, Kun Zhu, Zhaofeng Tian, Zhunan Cai, Jialin Yu, and Yi Liu, National Laboratories for Agrobiotechnology, China Agricultural University, Beijing, China 100094

\begin{abstract}
Han, C. G., Li, D. W., Xing, Y. M., Zhu, K., Tian, Z. F., Cai, Z. N., Yu, J. L., and Liu, Y. 2000. Wheat yellow mosaic virus widely occurring in wheat (Triticum aestivum) in China. Plant Dis. 84:627-630.

Wheat yellow mosaic virus (WYMV) was identified in 25 of 27 wheat (Triticum aestivum) samples from six provinces in China using reverse-transcription polymerase chain reaction. Wheat spindle streak mosaic virus was not detected. Thus, contrary to previous reports, WYMV was the only bymovirus detected in wheat in China. The cDNA fragments corresponding to coat protein coding regions of five WYMV isolates from China were cloned and sequenced. Deduced amino acid comparison of coat proteins among these five isolates, another Chinese WYMV isolate HC, and one isolate from Japan showed very high sequence conservation, particularly in both the N- and C- termini. However, a highly virulent isolate $\mathrm{HC}$ from Henan Province showed four amino acid substitutions in highly conserved amino acid positions which might play a role in its pathogenic variation.
\end{abstract}

Additional keyword: immunosorbent electron microscopy

Mosaic diseases of wheat (Triticum aestivum) have been reported in many countries in Europe, North America, and Asia. The causal agents were identified as Wheat yellow mosaic virus (WYMV) and Wheat spindle streak mosaic virus (WSSMV) in Japan and Canada $(13,15)$, respectively. In the 1960s, a mosaic disease was found in Sichuan, China (19) and spread gradually into the middle and lower valleys of the Yangtze and Huai Rivers in China, where it has caused severe yield loss of wheat in recent years $(4,6,21,27)$. Because of the similar characteristics in host range, symptom serology, and filamentous particle morphology of WYMV and WSSMV (18), and vector transmission by Polymyxa graminis, the nomenclature and classification of the two viruses has been controversial. The two viruses were considered to be strains of the same species of Bymovirus and were tentatively named WSSMV (10). The pathogens responsible for the wheat mosaic diseases in China were identified either as WSSMV or WYMV $(4,17,20$,

Corresponding author: J. Yu

E-mail: bnyvv@public.bta.net.cn

This research was supported by Nature Science Foundation of China (NSFC 39870489) and the High-Technology R\&D Program of China (863101-04-01-05).

Accepted for publication 2 February 2000.

Publication no. D-2000-0405-01R

(C) 2000 The American Phytopathological Society
$25,26,28)$. In addition, the Soilborne wheat mosaic virus was also found (1).

Based on partial nucleotide sequence, a Chinese isolate of WYMV HC was identified in China (23). In comparisons with the nucleotide sequence of WSSMV by Sohn et al. (16), it was concluded that WSSMV and WYMV were distinct from one another because they share only about $70 \%$ identity of the 3-terminal regions (23). The complete sequence of WYMV published recently presented evidence that the WYMV and WSSMV are two distinct viruses within the genus Bymovirus $(11,24)$, not strains of the same species as previously proposed. However, the bymovirus-incited wheat diseases, which occur along the valleys for more than $2,000 \mathrm{~km}$ in China, were described based on symptoms on different wheat cultivars, serological reactions with antisera to several bymoviruses, and viral particle characteristics with different results $(4,17,20,25,26,28)$. It is necessary to know whether the causal agent responsible for the damage in the area was WYMV, as reported previously, WSSMV, or both (23). Also, pathogenic differences among viral isolates were reported in China and Japan $(7,9)$ in which several wheat cultivars, including both resistant and highly susceptible lines, reacted to infections by each isolate with different severity of symptoms. Thus, an analysis of WYMV may give further insight into the relatedness of the different viral isolates and may reveal variations among WYMV strains at the molecular level.

In this article, we report the results of investigations of the distribution of by- moviruses in wheat in China. Variations among different WYMV isolates was assessed based on their deduced amino acid sequences of coat protein $(\mathrm{CP})$ regions.

\section{MATERIALS AND METHODS}

Virus isolates. In all, 27 wheat samples of different cultivars displaying either yellow mosaic or spindle streak mosaic were collected in March 1997 from the fields of provinces of Anhui, Henan, Hubei, Jiangsu, Sichuan, and Shaanxi along the Yangtze River. In addition, a WYMV isolate HC from Henan Province identified previously by serological tests and nucleotide analysis $(21,23)$ was used as a positive control.

RNA extraction. Infected leaf samples $(0.5 \mathrm{~g})$ were ground to fine powder in liquid nitrogen in a precooled mortar. Before the powdered tissue thawed, $5 \mathrm{ml}$ of extraction buffer $(0.02 \mathrm{M}$ Tris-HCl, $\mathrm{pH} 7.8$, $1 \%$ sodium dodecyl sulfate, $0.2 \mathrm{M}$ sodium chloride, and 0.005 M EDTA) and an equal volume of phenol:chloroform (1:1, vol/vol) were added with continuous homogenizing. The thawed mixture was extracted three times with phenol:chloroform and separated by centrifugation. Total RNA in the supernatant was precipitated by $2 \mathrm{M}$ lithium chloride in final concentration and washed three times with chilled $70 \%$ ethanol. The speed-vacuum-dried RNA was resuspended in sterile distilled water and stored at $-20^{\circ} \mathrm{C}$ until use.

Reverse-transcription polymerase chain reaction detection. Based on the nucleotide sequences of WYMV RNA1 (24; accession number AF067124) and WSSMV RNA1 (16), two pairs of oligonucleotides were designed to distinguish WYMV and WSSMV from one another by reverse-transcription polymerase chain reaction (RT-PCR) in the coding regions of two CPs. The WYMV primers were $5^{\prime}$ GAGCTCATGGCAGCTGAC-3' (PY-1) and $5^{\prime}$-AGGGGAGTACTGGTTTAGGT TAGT-3' (PY-2), which contained SacI and ScaI restriction sites (underlined), respectively; flanking the region of WYMV RNA1 from 6,481 to 6,498 and 7,362 to 73,85 nucleotides (nts; 24). The WSSMV primers were 5'-CGAGTACTGTTTGCA TTACGGTGGTTGTGA-3' (PS-1) and 5'CGAGTACTGATACAGATATACGACCA C-3' (PS-2), both of which contained a ScaI site (underlined) and corresponded to the WSSMV RNA1 at 3,488 to $3,517 \mathrm{nts}$ and 4,500 to 4,474 nts, respectively (16). 
Total RNA of each sample $(2 \mu \mathrm{g})$ was used for first-strand cDNA synthesis with 15 units of avian leukosis virus transcriptase using the Riboclone cDNA Synthesis Kit (Promega Corp., Madison, WI) according the manufacturer's instruction. Next, 2 mM magnesium chloride, 15 pmol each of the primers complementary to RNA1 3' terminals of WYMV (PY-2) or WSSMV (PS-2), was used to amplify the RNA samples. First-strand cDNA $(2 \mu \mathrm{l})$ was used as a template for the secondstrand cDNA. PCR reactions were carried out with 15 pmol of both primers to $5^{\prime}$ and 3 ' terminals of WYMV (PY-1 and PY-2) or WSSMV (PS-1 and PS-2) and 5 units Taq DNA polymerase (Promega Corp.). All amplifications were carried out for $30 \mathrm{cy}-$ cles of $94^{\circ} \mathrm{C}$ for $1 \mathrm{~min}, 50^{\circ} \mathrm{C}$ for $1 \mathrm{~min}$, and $72^{\circ} \mathrm{C}$ for $2 \mathrm{~min}$. The products were analyzed with $1 \%$ agarose gel electropho- resis. In the reactions, wheat samples of the WYMV isolate HC (21), an NY isolate of WSSMV (2), two cDNA clones of pGWY30 (23), and MoI39 (16) complementary to the RNA1 $3^{\prime}$ terminal regions of WYMV or WSSMV, respectively, were used as template controls.

cDNA cloning and sequencing. The PCR products were blunt-ended with T4 DNA polymerase for ligation into SmaI-cut pGEM-7Zf(+) (Promega Corp.). After screening of Escherichia coli DH5 $\alpha$ cells transformed with the recombinant plasmids by alkali cracking, the sizes of the cDNA inserts were estimated electrophoretically on $1 \%$ agarose gel (12). Sequences of the cDNA clones corresponding to the viral isolates from each province were determined by the dideoxy chain termination method in a DNA autosequencer (Model 377A, Perkin Elmer, Foster City, CA). All

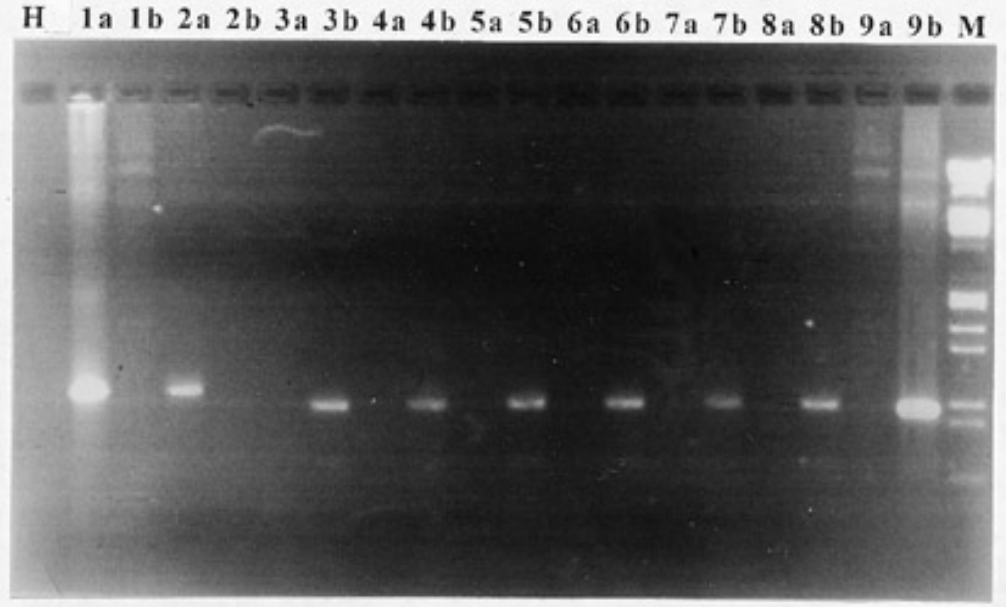

Fig. 1. Electrophoresis of reverse-transcription polymerase chain reaction products from diseased wheat plants. Lanes 1: Wheat spindle streak mosaic virus (WSSMV) cDNA clone of MoI39 as positive control; lanes 2: wheat plant infected by WSSMV NY isolate; lanes 3 to 8: wheat samples from Sichuan, Shaanxi, Hubei, Henan, Anhui, and Jiangsu Provinces, respectively; lanes 9: Wheat yellow mosaic virus (WYMV) cDNA clone of pGWY30 as positive control; $\mathrm{H}$ : healthy wheat; M: markers of $\lambda$-DNA digested with EcoRI and HindIII; primers complementary to a, WSSMV; or b, WYMV.

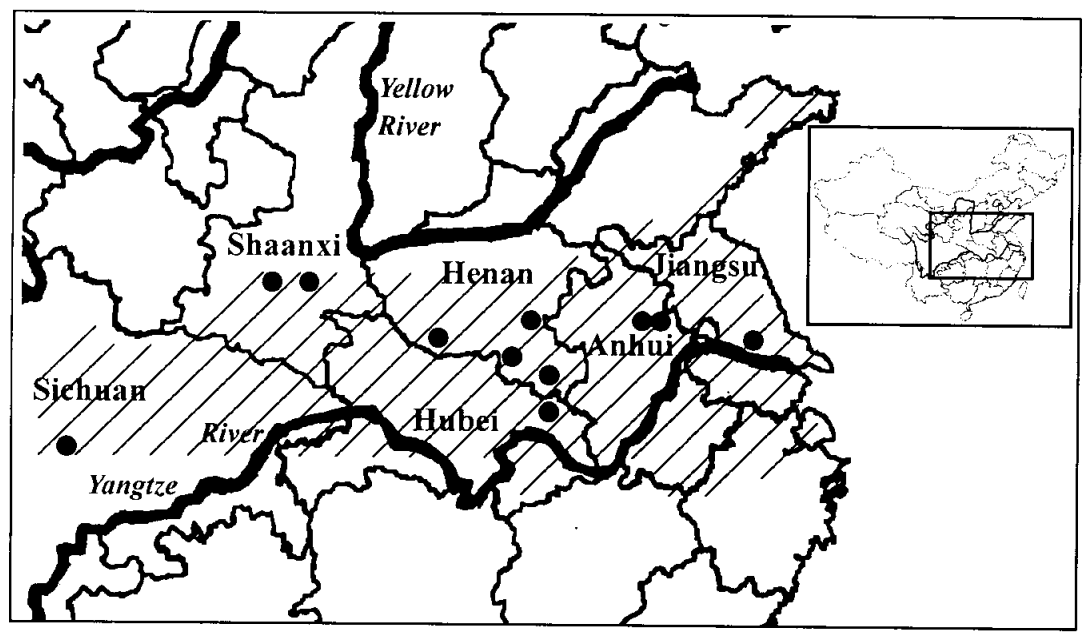

Fig. 2. Distribution of Wheat yellow mosaic virus (WYMV) detected in wheat in China. Black dots indicate counties in each province where samples were collected. The area where the occurrence of either Wheat spindle streak mosaic virus or WYMV was reported previously are marked with diagonal lines. parts of the cDNAs were sequenced in both orientations according to the manufacturer's instructions and several regions were confirmed by manually sequencing. All other molecular cloning techniques were performed as described by Sambrook et al. (12).

Antibodies and electron microscopy. Rabbit polyclonal antisera against WYMV or WSSMV provided by $\mathrm{T}$. Usugi were used in immunosorbent electron microscopy (ISEM) in parallel with RT-PCR detection. Virus particles in crude sap of the leaf samples were trapped on grids with both 10-fold diluted antibodies separately. The method for ISEM was described by Yu et al. (22)

Computer analysis. The nucleotide and amino acid sequences were analyzed and compared using the Genetyx-Mac Software (version 8.5, Software Development Co., Ltd., Japan).

\section{RESULTS}

Observation by ISEM. From 22 of 27 samples, virus particles of slightly flexuous filaments (data not shown) were trapped by either WYMV or WSSMV antibodies. In addition, a few rod-shaped particles were found in three samples from Henan, Anhui, and Jiangsu (data not shown). The ISEM, using both WYMV and WSSMV antisera, decorated virus particles heterologously; therefore, this technique could not be used to differentiate WYMV and WSSMV.

Species identification by RT-PCR. Approximately $0.9 \mathrm{~kb}$ of DNA was amplified in 25 samples, representing all six provinces, by the PY-1 and PY-2 primers (Fig. 1). No product was obtained with primers of PS-1 and PS-2 complementary to WSSMV, except for control templates of the NY isolate and the MoI39 cDNA. The primer pairs designed to amplify WYMV or WSSMV were highly specific, although, occasionally, a weak band was observed when the WYMV primers were used to detect the NY isolate. This result indicated that the filamentous virions in the samples from the valley were WYMV, not WSSMV. Thus, the only virus detected in wheat in Anhui, Henan, Hubei, Jiangsu, Sichuan, and Shaanxi Provinces was WYMV (Fig. 2).

Sequence comparison of CPs. The PCR products of five virus isolates (WYMV-DZ [Henan], WYMV-LT [Hubei], WYMV-YZ [Jiangsu], WYMV-YA [Sichuan], and WYMV-ZZ [Shaanxi]) were eluted from agarose gel after electrophoresis and cloned individually into the pGEM-7Zf(+) vector. The inserted fragments coding the $\mathrm{CP}$ gene were sequenced and compared with those of a Japanese isolate (JP; 11) and another Chinese isolate, HC, previously described (23). The deduced amino acids (aa) of the WYMV CP equaled 293 for most isolates, except for isolate DZ from Henan, which had 1 aa 
deleted at position 11. Among the different isolates, the amino acid sequences showed identities of 97.6 to $99.3 \%$, particularly in the regions of $\mathrm{N}$ terminus 110 aa and $\mathrm{C}$ terminus 55 aa. This conservation reflected that both ends of the WYMV CP may be surface epitopes of viral particles, similar to that of potyviruses (14). However, most differentiation was found in the core region of less than 130 aa in length between the isolate $\mathrm{HC}$ and all other isolates (Fig. 3). The amino acid residues of valine at position 118 and phenylalanine at position 144 were changed to isoleucine, and leucine at position 208 and phenylalanines at position 238 were replaced by valines.

\section{DISCUSSION}

WYMV and Barley yellow dwarf virus cause severe damage to wheat production in China $(3,5)$. These two viruses are found in southern and northern parts of the wheat-growing areas along the Yangtze and Yellow Rivers, respectively. In the middle to lower valleys of the Yangtze River, extending more than $2,000 \mathrm{~km}$, semi-winter hardy cultivars are grown under a similar climatic zone, where the lowest temperature in winter is about $0^{\circ} \mathrm{C}$ and wheat plants grow throughout the winter. Otherwise, winter dormancy is needed for wheat cultivars grown in the northern part of the country along the Yel- low River. In early spring, from February to March, wheat mosaic disease may break out under low temperatures of 8 to $14^{\circ}$. Diseased plants show symptoms of yellowing or chlorotic streak on leaves and stunting of the wheat plants without heading. Yield losses are estimated to range from 20 to $30 \%$ most years up to 50 to $70 \%$. The wheat yellow mosaic disease appeared in Sichuan in the 1960s (17), but the virus was not identified until 1980 as WSSMV (19). Since then, wheat viruses have been reported from different locations in China and the causal agents identified as WYMV or, preferably, WSSMV $(4,25,27)$. Based on this study (Fig. 2), WYMV is the only bymovirus detected. We believe that, to date, WYMV may be the only bymovirus present in the wheat production belt along the Yangtze and Yellow Rivers.

Pathogenic differentiation was reported among isolates of bymoviruses in wheat in China (6,7). A WSSMV isolate previously reported in Henan Province, where the WYMV isolate HC (23) was collected from the same location, showed stronger virulence than other isolates (8) similar to the WYMV isolate reported in Hokkaido (9). According to symptom severity and the latent period for symptom appearance after infection by different isolates, three pathogenic types are proposed for bymovirus isolates in China (8). Due to variations in virulence, some wheat cultivars appeared to be resistant only when they were grown within a restricted area. Many wheat cultivars become infected when they are planted in other provinces. By inoculating with viruliferous fungi in the greenhouse, the WYMV isolate $\mathrm{HC}$ also showed greater virulence than others in the different wheat cultivars tested (data not shown). Interestingly, the mutated CP amino acid sequence of WYMV isolate HC coincided with the pathogenic differences (Fig. 3). These mutated amino acids might represent a factor contributing to the pathogenic variations in WYMV. We are currently analyzing whether other parts of the WYMV genome may also contribute to this phenomenon.

\section{ACKNOWLEDGMENTS}

We thank A. Sohn, G. C. Bergstrom, and T. Usugi for their kind gifts of cDNA clone MoI39, WSSMV NY isolate, and antisera to bymoviruses, respectively; and S.-M. Wong for critical reading of the manuscript.

\section{LITERATURE CITED}

1. Cai, W. Q., Peng, X. X., and Mang, K. Q. 1983. Identification of soil-borne wheat mosaic virus caused wheat mosaic in Shandong Province China. Acta Phytopathol. Sin. 13(4):7-12

2. Carroll J. E., Gary S. M., and Bergstrom G. C. 1995. Use of antiserum to a New York isolate of wheat spindle streak mosaic virus to detect

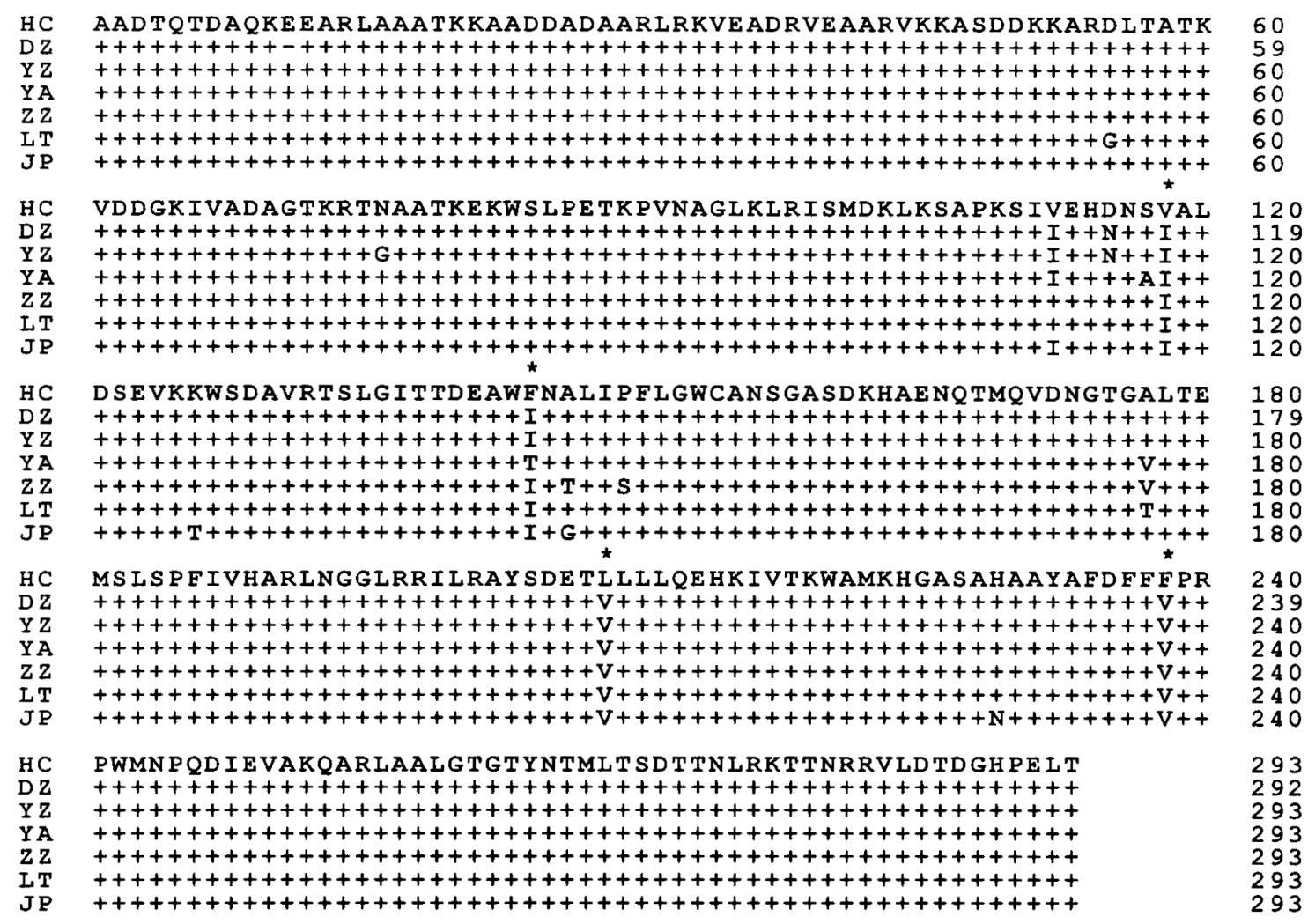

Fig. 3. Multiple alignment of predicated amino acid sequence of coat protein among different Wheat yellow mosaic virus (WYMV) isolates. HC: Henan isolate described previously (accession no. AF067124); DZ: Henan isolate (AJ240048); YZ: Jiangsu isolate (AJ240051); YA: Sichuan isolate (AJ240050); ZZ: Shaanxi isolate (AJ240052); LT: Hubei isolate (AJ240049); JP: Japan isolate reported by Namba et al (D86634); + indicates identical amino acid, indicates deleted amino acid, and * indicates the different residues between isolate $\mathrm{HC}$ and others. 
related bymoviruses from North America, Europe, and Asia. Plant Dis. 79(4):346353.

3. Chen, J. P. 1993. Occurrence of fungally transmitted wheat mosaic viruses in China. Ann. Appl. Biol. 123:55-61.

4. Chen, J. P., Ruan, Y. L., and Dong, M. J. 1989. Study on the pathogen of a wheat soilborne virus disease in China. Virol. Sin. 2:176-181.

5. Cheng, Z. M., Chen, J., Fu, C. S., and Li, Z. L. 1982. Purification and diagnosis of barley yellow dwarf virus on wheat. Acta Phytopathol. Sin. 12(1):58-60.

6. Hou, Q. S. 1993. A mini-review of fungally transmitted wheat viruses in China. Acta Phytopathol. Sin. 23(2):97-99.

7. Hou, Q. S., Cheng, Z. B., and Zhou, Y. J. 1993. A study on some properties of coat proteins of wheat spindle streak mosaic virus isolates with different pathogenicity. Jiangsu J. Agric. Sci. 9(2):11-16.

8. Hou, Q. S., Zhou, Y. J., Cheng, Z. B., and Xu, D. G. 1993. Comparison of pathogenicities and other characteristics among isolates of wheat spindle streak mosaic virus in China. Acta Phytopathol. Sin. 23(2):150

9. Kusume, T., Tamada, T., Hattori, H., Tsuchiya, T., Kubo, K., Abe, H., Namba, S., Tsuchizaki, T., Kishi, K., and Kashiwazaki, S. 1997. Identification of a new wheat yellow mosaic virus strain with specific pathogenicity towards major wheat cultivars grown in Hokkaido. Ann. Phytopathol. Soc. Jpn. 63:107-109.

10. Murphy, F. A., Fauquet, C. M., Bishop, D. H. L., Ghabrial, S. A., Jarvis, A. W., Martelli, G. P., Mayo, M. A., and Summers, M. D. 1995. Virus Taxonomy. Classification and Nomenclature of Virus. Sixth Report of the International Committee on Taxonomy of Viruses.
Springer, Wien, New York (Arch. Virol. [Suppl.]10).

11. Namba, S., Kashiwazaki, S., Lu, X., Tamura, M., and Tsuchizaki, T. 1998. Complete nucleotide sequence of wheat yellow mosaic bymovirus genomic RNAs. Arch. Virol. 143:631-643

12. Sambrook, J., Fritsch, E. F., and Maniatis, T. 1989. Molecular Cloning: A Laboratory Manual. 2nd ed. Cold Spring Harbor Laboratory Press, Cold Spring Harbor, NY.

13. Sawada, E. 1927. Control of wheat yellow mosaic virus. J. Plant Prot. 14:444-449.

14. Shukla, D. D., Strike. S. L., Tracy. P. M., Gough, K. H., and Ward, C. W. 1988. The N and $\mathrm{C}$ termini of the coat proteins of potyviruses are surface-located and the $\mathrm{N}$ terminus contains the major virus-specific epitopes. J. Gen. Virol. 69:1497-1580.

15. Slykhuis, J. T., and Polak, Z. 1969. Verification of wheat spindle streak mosaic virus as a cause of mosaic of wheat in Ontario. Can. Plant Dis. Surv. 49:108-111.

16. Sohn, A., Schenk, P., Signoret, P. A., Schmitz, G., Schell, J., and Steinbiss, H. H. 1994. Sequence analysis of the 3'-terminal half of RNA1 of wheat spindle streak mosaic virus. Arch. Virol. 135:279-292.

17. Tao, J. F., Qin, J. Z., Xiao, J. H., Shen, Y. Z., Zhao, F. Z., Li, T. J., Xie, Y. Y., He, D. F., Rao, Y. H., and Huang, X. H. 1980. Studies on the soil-borne yellow mosaic virus of wheat in Sichuan. Acta Phytopathol. Sin. 10(1):15-25.

18. Usugi, T., Kashiwazaki, S., Omura, T., and Tsuchizaki, T. 1989. Some properties of nucleic acids and coat proteins of soil-borne filamentous viruses. Ann. Phytopathol. Soc. Jpn. 55:26-31.

19. Wang, M. Q., Liu, G. S., and Lu, X. H. 1980. A primary confirmation on wheat spindle streak mosaic virus occurring in China. Agric Sci. Technol. Sichuan (1):34-35.

20. Wu, S. Q., Cui, B. T., Zhang, Z. H., Wang, W. Y., and $\mathrm{Wu}$, Y. L. 1985. Preliminary study on wheat spindle streak mosaic virus. Acta Phytopathol. Sin. 15(1):58-59.

21. Xing, Y. M., Yu, J. L., Yan, L. Y., Li, D. W. Cai, Z. N., and Liu, Y. 1994. Identification, purification and serology of a fungus-borne wheat virus. J. Agric. Biotechnol. 2(1):91 95

22. Yu, J. L., and Liu, Y. 1987. The occurrence of three viruses in hop (Humulus lupulus) in China. Plant Pathol. 36:38-44.

23. Yu, J. L., Yan, L. Y., Feng, J. D., Li, D. W. Cai, Z. N., and Liu Y. 1995. Sequence analysis of the 3'-terminal of fungus-transmitted wheat mosaic virus RNA1 isolated in China. Chin. J. Virol. 11(3):248-254

24. Yu, J. L., Yan, L. Y., Su, N., Hou, Z. J., Li, D. W., Han, C. G., Yang, L. L., Cai, Z. N., an Liu, Y. 1999. Analysis of nucleotide sequence of wheat yellow mosaic virus genomic RNAs. Sci. China (Ser. C) 42(5):554-560.

25. Yu, S. Q., Chen, Z. Y., Xu, L. S. Zhang, R. P. and Wang, M. Q. 1986. Wheat yellow mosaic virus disease in China. Acta Phytophylacica Sin. 13(4):217-220.

26. Zhang, Q. F., Zhu, X. S., Liu, T. F., and Zhang, L. J. 1988. Preliminary study on identification of wheat spindle streak mosaic virus in Shaanxi Province. Virol. Sin. 1:94-97.

27. Zhou, G. H., Chen, J. B., and Chen, S. M. 1989. Identification, purification and partial characterization of the wheat spindle streak mosaic virus. Chin. J. Virol. 5(1):46-51.

28. Zhou, G. H., Chen, J. B., and Chen S. M. 1990. Comparative identification of wheat spindle streak mosaic virus from differen places in China. Acta Phytopathol. Sin. 20(2):107-110 